International Journal of Food Science, Nutrition and Dietetics (IJFS)

ISSN 2326-3350

\title{
Polyphenol-rich fruits attenuate impaired endothelial function induced by glucose and free fatty acids in vitro in human endothelial cells
}

Research Article

Chang $\mathrm{C}^{1}$, Kangath $\mathrm{A}^{2}$, Burton-Freeman $\mathrm{B}^{2}$, Jackson L S ${ }^{1}$, Edirisinghe $\mathrm{I}^{2 *}$

${ }^{1}$ Center for Food Safety and Applied Nutrition, U.S. Food and Drug Administration, 6502 South Archer Road, Bedford Park, Illinois, 60501 USA.

${ }^{2}$ Institute For Food Safety and Health, Illinois Institute of Technology, 6502 South Archer Road, Bedford Park, 60501, Illinois, USA

\begin{abstract}
Elevated concentrations of plasma glucose and free fatty acids (FFA) are associated with impaired endothelial function increasing risk of cardiovascular diseases. Previous studies suggested that fruits rich in polyphenolic compounds modulate endothelial cell migration and capillary-like tube formation via a redox-sensitive mechanism. We hypothesized that polyphenol-rich extracts of strawberry (SB) and wild blueberry (WB) would attenuate relatively high concentrations of glucose and/or FFA-mediated impaired cell migration and capillary-like tube formation in vitro in human umbilical vein endothelial cells (HUVECs). HUVECs treated with high FFA and combinations of glucose and FFA showed significantly reduced cell migration and capillary-like tube formation compared to the PBS control $(\mathrm{p}<0.05)$. However, HUVEC pre-treated with SB or WB extracts significantly increased cell migration and capillary-like tube formation in cells treated with FFA or a combination of FFA and glucose compared to cells exposed to the same nutrients/combinations alone. The results from this study suggest that berry fruits may play a role in promoting cardiovascular health especially in individuals with high blood glucose and/or FFA levels.
\end{abstract}

Keywords: Wild Blueberry; Strawberry; Glucose; Free Fatty Acids; Cell Migration; Tube Formation.

\section{*Corresponding Author:}

Indika Edirisinghe,

Institute for Food Safety and Health, Illinois Institute of Technology, 6502, South Archer Road, Bedford Park, 60501, Illinois, USA.

Tel: 708563 8178; Fax: +55-11-5573-9652

E-mail: iedirisi@iit.edu

Received: February 22, 2014

Accepted: March 22, 2014

Published: March 24, 2014

Citation: Edirisinghe I, et al (2014) Polyphenol-rich fruits attenuate impaired endothelial function induced by glucose and free fatty acids in vitro in human endothelial cells. Int J Food Sci Nutr Diet. 3(3), 99-108. doi: http://dx.doi.org/10.19070/2326-3350-1400020

Copyright: Edirisinghe $\mathbf{I}^{\mathcal{O}} 2014$ This is an open-access article distributed under the terms of the Creative Commons Attribution License, which permits unrestricted use, distribution and reproduction in any medium, provided the original author and source are credited.

\section{Introduction}

The cluster of medical conditions that make up insulin resistance (IR) places an individual at risk of developing type 2 diabetes (T2D), atherosclerosis and other chronic diseases. Elevated glucose and free fatty acids (FFA) are evident in individuals with IR and are associated with oxidative stress and inflammation. $[1,2]$ Oxidative stress and inflammation play a significant role in the etiology of endothelial dysfunction [3]. Reduced endothelial function is closely associated with elevated concentrations of glucose and FFA in plasma resulting in oxidative stress and inflam- mation $[4,5]$. Endothelial dysfunction precedes the development of atherosclerosis, a chronic disease characterized by abnormal thickening and hardening of the arterial walls with resulting loss of vasodilation, cell migration and angiogenesis [6]. As a result of these symptoms, individuals with atherosclerosis have a higher risk of developing a stroke or heart attack and reduced recovery from tissue injury [6].

There are human clinical trials and epidemiological studies that have demonstrated that dietary antioxidants derived from plant foods may have preventive and therapeutic roles in a number of chronic diseases. [7]We and others have shown that polyphenolic compounds derived from fruit extracts modulate endothelial function in vitro and reduce blood pressure in vivo. [8-11] Furthermore, we have shown that extracts derived from strawberry, wild blueberry and cranberry increased cell migration and angiogenesis in vitro in endothelial cells via a mechanism that involved redox-sensitive phosphoinositosol 3 kinase (PI3K)/ protein kinase B (Akt). [9] Several studies have demonstrated that endothelial cells exposed to high concentrations of plasma glucose and FFA exhibit structural and functional changes and are under conditions of increased oxidative stress.[5], [12-14] However, data are lacking on whether polyphenolic-rich berry fruit could repair endothelial cell damage and dysfunction imposed by elevated concentrations of plasma glucose or FFA typically found in the fasting and postprandial states of individuals with diabetes and pre-diabetes. Therefore, in the present investigation, we tested the hypothesis that berry extracts (strawberry extracts- SB and wild blueberry extracts-WB) attenuate high glucose- and/or FFA-induced impaired cell migration and angiogenesis in vitro in human umbilical vein endothelial cells (HUVECs). 


\section{Materials and Methods}

\section{Berry Materials and Reagents}

Fresh, lowbush wild blueberries ( $V$. angustifolium) (WB) were provided by the Wild Blueberry Association of North America (WBANA, Orono, ME). The fresh WB were freeze-dried using a Millrock Bench-Top Freeze-Dryer (Kingston, NY). The dried WB were ground into a powder using a coffee mill, and stored at $-80^{\circ} \mathrm{C}$. Freeze-dried strawberry (SB) powder was supplied by the California Strawberry Commission (CSC, Watsonville, CA) and stored at $-80^{\circ} \mathrm{C}$ until use. All chemicals were purchased from Sigma Aldrich, St. Louis MO, unless otherwise stated.

\section{Sample Preparation for Cell Culture Studies}

Stock extracts of SB and WB were prepared by suspending freezedried SB and WB powders $(100 \mathrm{mg})$ in $1 \mathrm{~mL}$ phosphate buffered saline (PBS; $\mathrm{pH} 7.4$ ) and vortexing the mixtures for 1 minute. The suspensions were centrifuged (Eppendorf 5810R centrifuge) at $1500 \mathrm{rpm}$ for 5 minutes, and then filtered through sterile $0.22 \mu \mathrm{m}$ nylon syringe filters prior to use in cell culture experiments. Glucose $(270 \mathrm{mg}$ ) was mixed with $1 \mathrm{~mL}$ sterile PBS to make a stock solution for all the glucose treatments. A stock FFA solution was prepared by mixing $500 \mathrm{~mL}$ of $0.1 \mathrm{~N} \mathrm{NaOH}$ containing $26 \mathrm{mg}$ of palmitic acid with $50 \mathrm{mg}$ of endotoxin-free bovine serum albumin (BSA) in $500 \mathrm{~mL}$ phosphate buffered saline (PBS), and heating the mixture at $70^{\circ} \mathrm{C}$ with constant stirring.

\section{In Vitro Cell Culture}

Human umbilical vein endothelial cells (HUVECs) were purchased from Lonza (Washington, DC) and grown in endothelial cell growth medium (EGM, Lonza, Washington, DC) supplemented with $4 \%$ fetal bovine serum (FBS). The glucose concentration in the media was $5.5 \mathrm{mM}$. Cell viability was tested using the trypan blue exclusion test. [9] Apoptosis effects were investigated using the Caspase 9 Colorimetric Activity Assay Kit (Millipore, Waltham, MA). All experiments were conducted with HUVEC at the second or third passage. Cells were pre-incubated in $2 \%$ FBS medium for 2-3 h before any treatments. [9]

\section{Effects of Berry Fruit Extracts on Endothelial Cell Migra- tion}

The cell migration assay (scratch assay) was performed to investigate the effect of SB and WB extracts $(0.2 \mathrm{mg} / \mathrm{mL})$ on endothelial cell migration for HUVECs treated with glucose and/or FFA. Our previous data suggested that treating cells with $0.2 \mathrm{mg} / \mathrm{mL}$ SB or WB extracts for 5-8 h did not significantly affect cell viability or induce apoptosis. [9] HUVECs were grown ( $>90 \%$ confluent) in 6-well plates containing 4\% FBS and then were starved for 2-3 $\mathrm{h}$ in a media containing 2\% FBS. Each well containing a monolayer of HUVEC was scraped in a straight line with a 200 $\mu \mathrm{L}$ sterile pipet tip. Cell debris was removed by washing the plate with PBS solution twice. HUVECs were pre-treated with $0.2 \mathrm{mg} /$ $\mathrm{mL}$ of $\mathrm{SB}$ or WB extracts in a media containing $2 \%$ serum and then incubated for $2 \mathrm{~h}$ at $37^{\circ} \mathrm{C}$ in a humidified atmosphere containing $5 \% \mathrm{CO}_{2}$. Subsequently the same cells were treated with glucose solutions $(10 \mathrm{mM}, 15 \mathrm{mM}$ or $20 \mathrm{mM})$, FFA solutions $(0.5$ $\mathrm{mM}, 1 \mathrm{mM}$ or $2 \mathrm{mM})$, or solutions containing glucose $+\mathrm{FFA}$ $(10 \mathrm{mM}+0.5 \mathrm{mM}, 15 \mathrm{mM}+1 \mathrm{mM}$ or $20 \mathrm{mM}+2 \mathrm{mM})$. Parallel control experiments were carried out with cells treated with
PBS solution and with various concentrations of glucose, FFA, and FFA + glucose without pretreatment with SB or WB extracts. The number of cells that migrated beyond the scratched lines at 0 and $8 \mathrm{~h}$ were counted under $40 \mathrm{X}$ magnification level using an Olympus CKX41 microscope (Center Valley, PA) by a single investigator in a blinded manner.

\section{Effects of Berry Fruit Extracts on Capillary-like Tube For- mation in Vitro in HUVECs}

In vitro experiments using HUVECs evaluated the effects of $\mathrm{SB}$ and WB extracts $(0.2 \mathrm{mg} / \mathrm{mL})$ on the formation of capillarylike tube formations that mimic new blood vessel formation (angiogenesis). [9] HUVECs (passage 2 or 3) were seeded in 6-well plates in medium containing $4 \%$ FBS until $80 \%$ confluent. Prior to experiments, $4 \%$ FBS medium was replaced with $2 \%$ FBS medium for 2-3 h to starve cells. The cells were then incubated with $\mathrm{SB}$ or WB extracts for $2 \mathrm{~h}$ followed by treatment with glucose solutions (final concentrations in the media- $10 \mathrm{mM}, 15 \mathrm{mM}$ or 20 $\mathrm{mM}$ ), FFA solutions (final concentrations in the media- $0.5 \mathrm{mM}$, $1 \mathrm{mM}$ or $2 \mathrm{mM}$ ), or solutions containing glucose + FFA (final concentrations in the media $10 \mathrm{mM}+0.5 \mathrm{mM}, 15 \mathrm{mM}+1 \mathrm{mM}$ or $20 \mathrm{mM}+2 \mathrm{mM}$ ) overnight. After the overnight incubation, cells were washed with PBS. Cells $(10,000)$ were plated from each experimental well in 48-well plates that had been pre-coated with $100 \mu \mathrm{L}$ of growth factor-reduced Matrigel Matrix (BD Bioscience, Franklin Lakes, NJ). Capillary-like tube formation was observed and photographed using 40x magnification levels using an Olympus CKX41 microscope (Center Valley, PA) after 5, 10, 15 and $24 \mathrm{~h}$. All completed capillary-like branches were counted by a single investigator in a blinded manner. Angiogenesis was quantified by counting the number of capillary-like tubes formed per microscopic field.

\section{Anthocyanin Analysis of Wild Blueberry (WB) Powder}

Anthocyanins in the freeze-dried WB samples were identified and quantified using methods previously described. [9] Briefly, extracts of WB were prepared by extracting freeze-dried powder with a mixed solvent containing acetone:water:acetic acid (70:29.5:0.5, $\mathrm{v} / \mathrm{v} / \mathrm{v}$ ) for $1 \mathrm{~h}$, centrifuging the extract at 10,000 $\mathrm{g}$ for $20 \mathrm{~min}$, and finally filtering through Whatman no. 2 filter paper. An Accela HPLC system, equipped with a Synergi RP-Max 250 x $2.0 \mathrm{~mm}$ (4 $\mu \mathrm{m}$ i.d.) column (Phenomenex, Torrance, CA), photodiode array (PDA) detector and Exactive Orbitrap mass spectrometer fitted with an electrospray interface (ESI) probe (Thermo Fisher Scientific), was used to separate and identify the anthocyanins in WB extract using chromatographic conditions described previously. [9] Quantification of anthocyanins was done using a Waters (Milford, MA) Alliance 2795 HPLC system equipped with a Synergi Max -RP column (150 x 3.0 mm; $4 \mu \mathrm{m}$ i.d.; Phenomenex), model 996 PDA detector, model 2475 fluorescence detector, and Quattro Micro triple quadrupole mass spectrometer using the conditions described by Tulio et al. [9] MassLynx (V.4.1) software was used to identify and quantify anthocyanins in extracts. Identification of anthocyanins was also accomplished by comparing the retention times of the peaks obtained during HPLC separations with those from reference standards and published data as previously described. [9] Analyses of WB powder were done in triplicate.

\section{Anthocyanin Analysis of Strawberry (SB) Powder}

Strawberry (SB) powder used in this study was analyzed for antho- 
cyanins using LC-MS/MS as described previously. [15] Briefly, the freeze-dried strawberry powder was extracted with acetone:water (70:30, v/v) and the resulting mixture was filtered through a 0.2 $\mu \mathrm{m}$ glass filter. The extract was dried under a nitrogen stream, then dissolved in water:acetonitrile (90:1). Analysis of anthocyanins in SB extracts was performed on an Agilent 1200 Rapid Resolution HPLC system equipped with a Luna RP C-18 column (100 mm x $2.0 \mathrm{~mm}, 3 \mathrm{~mm}$ i.d.; Phenomenex), and 6460 triple quadruple mass spectrometer (Santa Clara, CA), using chromatographic and MS conditions described by Edirisinghe et al.[15] Anthocyanin compounds in the extracts were identified by retention times relative to standards and MS2 fragmentation patterns. Reference standards were used to quantify identified compounds, while theoretical molecular weights and published fragmentation patterns were used to confirm identities of anthocyananins without reference standards as described previously.[15] SB powder analyses were done in triplicate.

\section{Total Phenolic and Vitamin $\mathrm{C}$ analyses}

Total phenolic and ascorbic acid concentrations in WB and SB powders were determined by the colorimetric assay developed by Slinkard and Singleton, [16] and the HPLC "procedure" as described by Sanchez Mata et al.[17], respectively.

\section{Statistical Analyses}

The Sigma Plot 11 statistical program (Systat Software, Inc. Chicago, IL) was used to analyze the data. Normality and equal variance tests were performed followed by one-way ANOVA and multiple comparison tests. Treatments were considered significantly different at $p<0.05$. Results were given as the mean $\pm \mathrm{SD}$ of at least three independent trials.

\section{Results}

Effects of fruit extracts with glucose and/or free fatty acid on cell migration in vitro in HUVECs

Glucose: HUVEC cell migration was assessed by the scratch assay. Cell viability and apoptosis in response to $\mathrm{SB}$ and WB extracts were not significantly affected at the concentrations of $0.2 \mathrm{mg} /$ $\mathrm{mL}$ for 5-8 h post-treatment ( $p<0.05$, data not shown). Cell migration was significantly enhanced in response to pre-treatment of HUVECs with $0.2 \mathrm{mg} / \mathrm{mL} \mathrm{SB}$ or WB extracts compared to the PBS control ( $p<0.05$, Figures 1 and 2, control group). However, no significant differences $(p>0.05)$ in the cell migration were observed between cells pretreated with SB or WB. Cell migration was significantly $(\mathrm{p}<0.05)$ enhanced of the cells treated with 10 $\mathrm{mM}$ concentration of glucose compared to the PBS control, and pre-treatment of cells with either SB or WB did not significantly differ from $10 \mathrm{mM}$ alone $(\mathrm{p}>0.05)$. At the highest concentrations of glucose $(15 \mathrm{mM}$ and $20 \mathrm{mM})$, cell migration was not significantly different from the PBS control $(\mathrm{p}>0.05)$. However, pretreatment of cells with either SB or WB enhanced cell migration significantly with $15 \mathrm{mM}$ glucose $+\mathrm{SB}$ only, but both fruits with $20 \mathrm{mM}$ glucose compared to their respective controls without SB or $\mathrm{WB}$, or the PBS control $(\mathrm{p}<0.05)$.

FFA: Treatment of HUVECs with 0.5, 1 and $2 \mathrm{mM}$ of FFA significantly reduced cell migration compared to the PBS control $(\mathrm{p}<0.001)$ (Figure 3). At the $0.5 \mathrm{mM}$ concentration, pre-treatments with SB extract did not significantly increase cell migration compared to the $0.5 \mathrm{mM}$ treatment without SB pre-treatment $(\mathrm{p}>0.05)$. However, WB significantly enhanced cell migration compared to $0.5 \mathrm{mM}$ FFA alone $(\mathrm{p}<0.05)$ and showed no sig-

Figure 1: Effect of strawberry and wild blueberry extracts on glucose and/or FFA-mediated impaired cell migration in-vitro in HUVECs

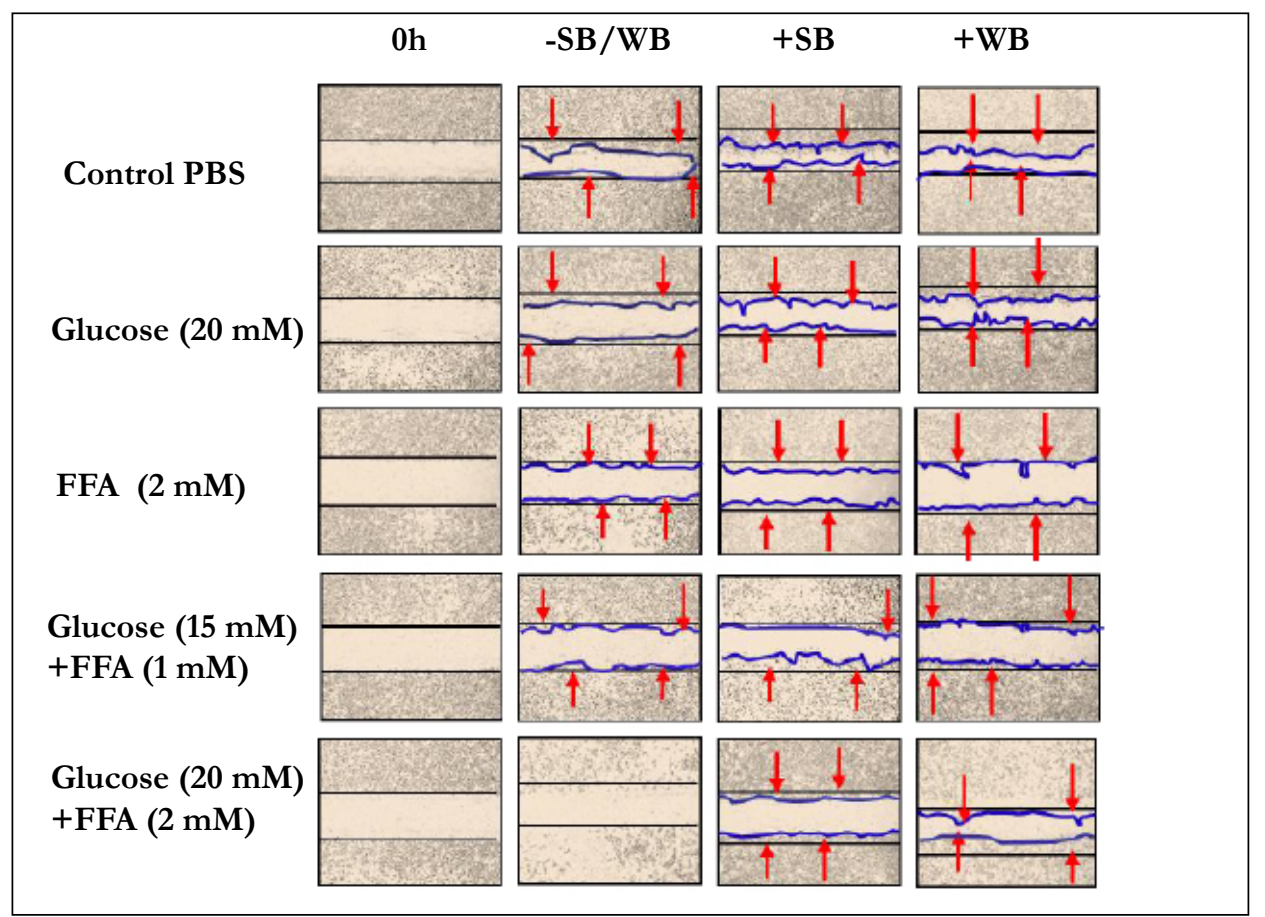

HUVECs were starved for 2-3 h in a media containing $2 \%$ FBS. Each well containing a monolayer of HUVEC was scraped (straight line) using a $200 \mu \mathrm{L}$ sterile pipet tip. Cells were pre-treated with $0.2 \mathrm{mg} / \mathrm{ml}$ of SB or WB extracts in a media containing $2 \%$ serum and then incubated for $2 \mathrm{~h}$ at $37{ }^{\circ} \mathrm{C}$ in a humidified atmosphere containing 5\% CO2. Then HUVECs were treated with glucose solutions (Final concentration in the media-10 mM, $15 \mathrm{mM}$ or $20 \mathrm{mM}$ ), FFA solutions (final concentration in the media $-0.5 \mathrm{mM}, 1 \mathrm{mM}$ or $2 \mathrm{mM}$ ), or solutions containing glucose + FFA (final concentration in the media $10 \mathrm{mM}+0.5 \mathrm{mM}$, $15 \mathrm{mM}+1 \mathrm{mM}$ or $20 \mathrm{mM}+2 \mathrm{mM}$ ) and incubated for $15 \mathrm{~h}$ at $37^{\circ} \mathrm{C}$ in a humidified incubator containing $5 \% \mathrm{CO} 2$. The representative figures shows number of cells that migrated beyond the scratched lines at 0 and $8 \mathrm{~h}$. Cells were counted under 40X magnification level by a single investigator in a blinded manner. 
Figure 2: Histograms represent mean \pm SD cell migration beyond the scratch lines in the presence of different concentrations of glucose

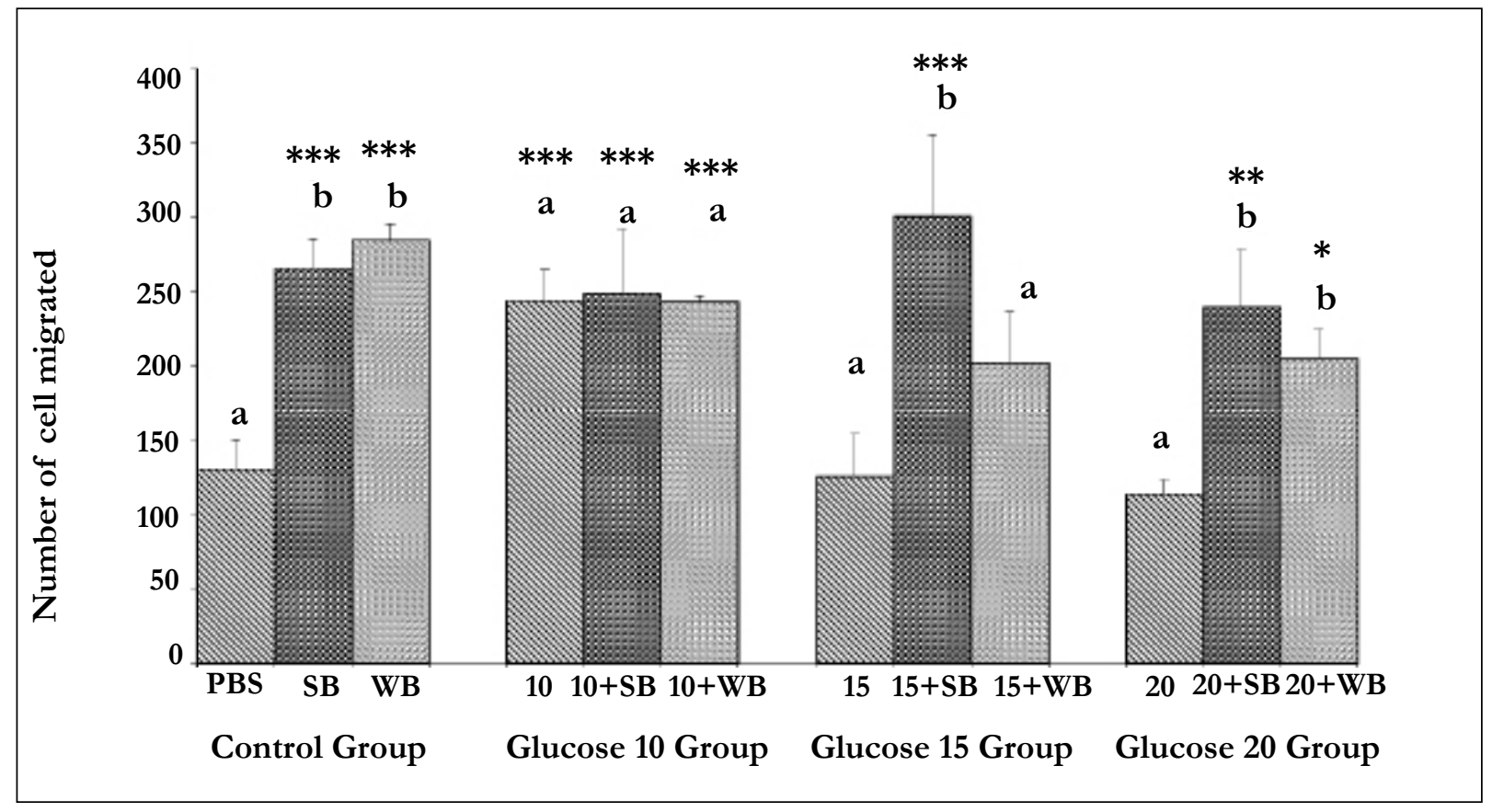

Histograms represent mean \pm SD cell migration beyond the scratch lines in the presence of different concentrations of glucose (Glucose 10 group-10 mM, Glucose 15 group-15 mM and Glucose 20 group- $20 \mathrm{mM}$ - different treatment groups) in the presence of strawberry (SB) or wild blue berry (WB) extracts in vitro in HUVECs. Different letters represent significant difference $(\mathrm{p}<0.05)$ within each treatment group. ${ }^{*}, \mathrm{p}<0.05,{ }^{* *}, \mathrm{p}<0.01, * * *, \mathrm{p}<0.001$, vs. PBS treated control, $\mathrm{n}=3$.

Figure 3: Histograms represent mean \pm SD cell migration beyond the scratch lines in the presence of different concentrations of free fatty acids

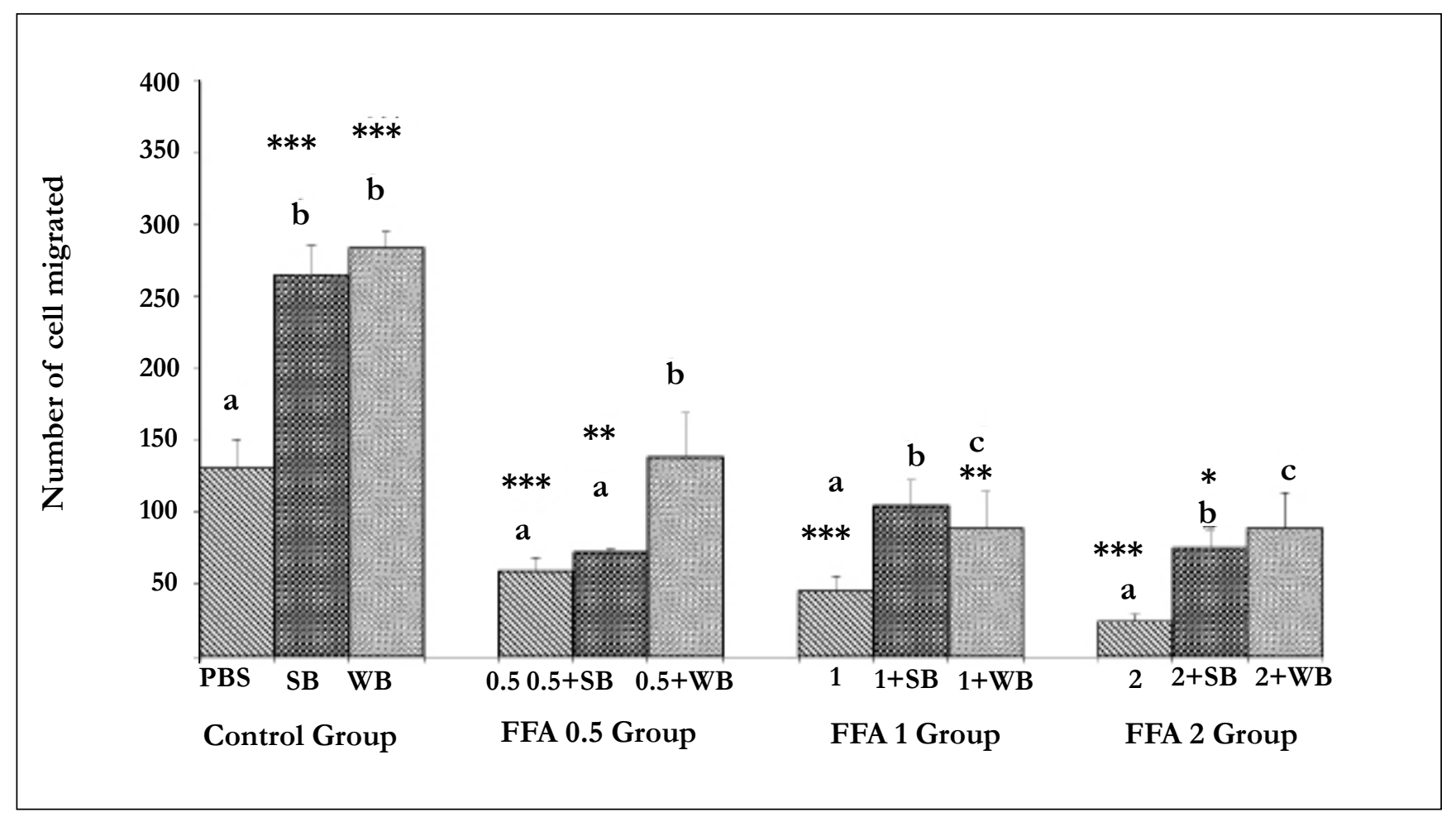

Histograms represent mean \pm SD cell migration beyond the scratch lines in the presence of different concentrations of free fatty acids (FFA 0.5 group- $0.5 \mathrm{mM}$, FFA 1 group- $1 \mathrm{mM}$, FFA 2 group- $2 \mathrm{mM}$ - different treatment groups) in the presence of strawberry (SB) or wild blue berry (WB) extracts in vitro in HUVECs. Different letters represent significant difference $(\mathrm{p}<0.05)$ within each treatment group. ${ }^{*}, \mathrm{p}<0.05, * *, \mathrm{p}<0.01, * * *, \mathrm{p}<0.001$, vs. PBS treated control, $\mathrm{n}=3$. 
Figure 4: Histograms represent mean \pm SD cell migration beyond the scratch lines in the presence of different concentrations

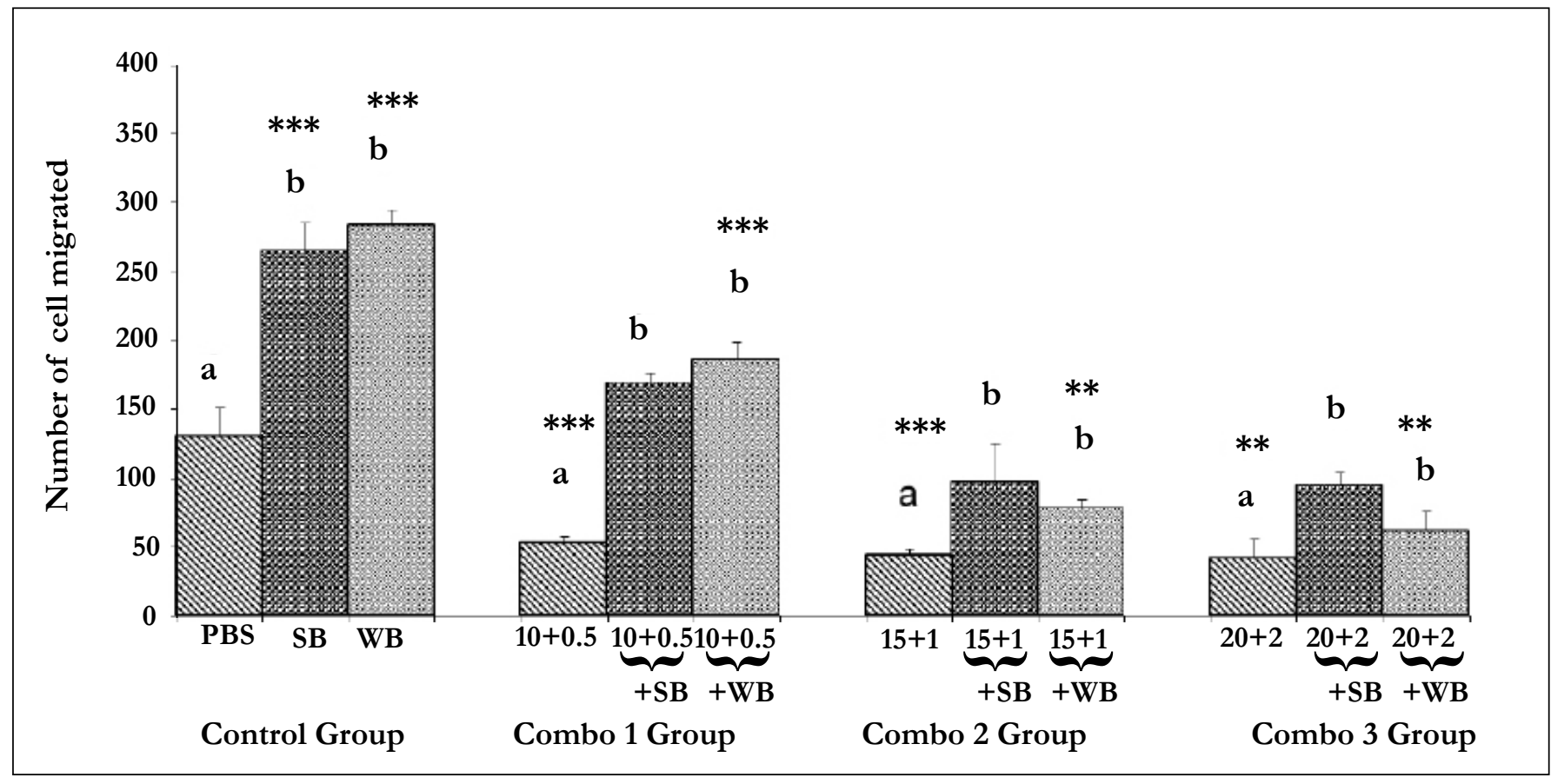

Histograms represent mean \pm SD cell migration beyond the scratch lines in the presence of differentconcentrations of (Combo 1 group-glucose $10 \mathrm{mM}+\mathrm{FFA} 0.5 \mathrm{mM}$, Combo 2 group-glucose $15 \mathrm{mM}+$ FFA $1 \mathrm{mM}$, Combo 3 group-glucose $20 \mathrm{mM}+\mathrm{FFA} 2 \mathrm{mM}$ ) in the presence of strawberry (SB) or wild blue berry (WB) extractsin vitro in HUVECs. Differentletters represent significant difference $(\mathrm{p}<0.05)$ within each treatment group. ${ }^{*}, \mathrm{p}<0.05, * *, \mathrm{p}<0.01,{ }^{* * *}, \mathrm{p}<0.001$, vs. PBS treated control, $\mathrm{n}=3$.

Figure 5: Effect of strawberry and wild blueberry extracts on glucose and/or FFA-mediated impaired capillary like tube formation in-vitro in HUVECs.

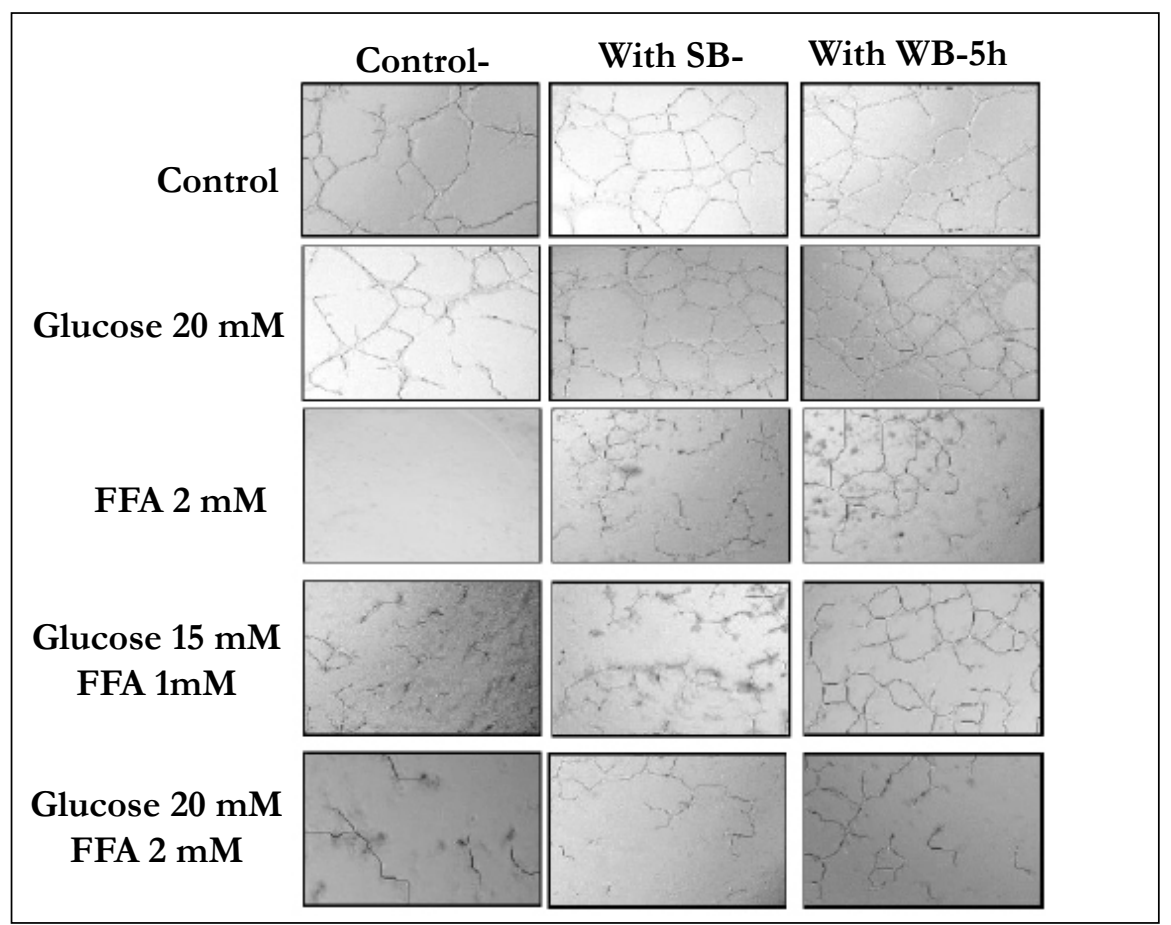

HUVECs were starved for $2-3 \mathrm{~h}$ in a media containing $2 \% \mathrm{FBS}$. Cells were pre-treated with $0.2 \mathrm{mg} / \mathrm{ml}$ of SB or WB extracts in a media containing $2 \%$ serum and then incubated for $2 \mathrm{~h}$ at $37{ }^{\circ} \mathrm{C}$ in a humidified atmosphere containing $5 \% \mathrm{CO}_{2}$. Then HUVECs were treated with glucose solutions (final concentration in the media $10 \mathrm{mM}, 15 \mathrm{mM}$ or $20 \mathrm{mM}$ ), free fatty acid solutions (final concentration in the media FFA- $0.5 \mathrm{mM}, 1 \mathrm{mM}$ or $2 \mathrm{mM}$ ), or solutions containing glucose + FFA (final concentration in the media $10 \mathrm{mM}+0.5 \mathrm{mM}, 15 \mathrm{mM}+1 \mathrm{mM}$ or $20 \mathrm{mM}+2 \mathrm{mM}$ ) and incubated for $15 \mathrm{~h}$ at $37^{\circ} \mathrm{C}$ in a humidified incubator containing $5 \% \mathrm{CO}_{2}$. HUVECs were lifted and seeded on a Matrigel matrix to investigate capillary-like tube formation. The representative figures shows number of capillary-like tubes formed at $5 \mathrm{~h}$ and capillary like branches were counted under $40 \mathrm{X}$ magnification level by a single investigator in a blinded manner.

nificant difference from the PBS control ( $\mathrm{p}>0.05)$. Pre-treatment of HUVECs with SB and WB extracts significantly attenuated FFA-induced impaired cell migration at $1 \mathrm{mM}$ and $2 \mathrm{mM}$ of FFA concentration $(p<0.05)$ although the enhanced effects were not significantly different compared to the PBS control $(\mathrm{p}>0.05)$

Nutrient Combination: Cell migration was significantly decreased $(p<0.05)$ for all glucose/FFA combinations tested (glu- cose $10 \mathrm{mM}+$ FFA $0.5 \mathrm{mM}, 15 \mathrm{mM}$ glucose $+1 \mathrm{mM}$ FFA and 20 $\mathrm{mM}$ glucose $+2 \mathrm{mM}$ FFA) compared to the PBS control (Figure 4). For all combinations tested, pre-treatment of cells with either $\mathrm{SB}$ or WB resulted in significantly enhanced cell migration compared to their respective control treatments without SB or WB $(p<0.05)$, but not significant different $(p>0.05)$ compared to the PBS control; except for the glucose $10 \mathrm{mM}+$ FFA $0.05 \mathrm{mM}$ in WB group. 
Figure 6. Histograms represent mean \pm SD capillary-like tube formation in the presence of different concentrations of glucose

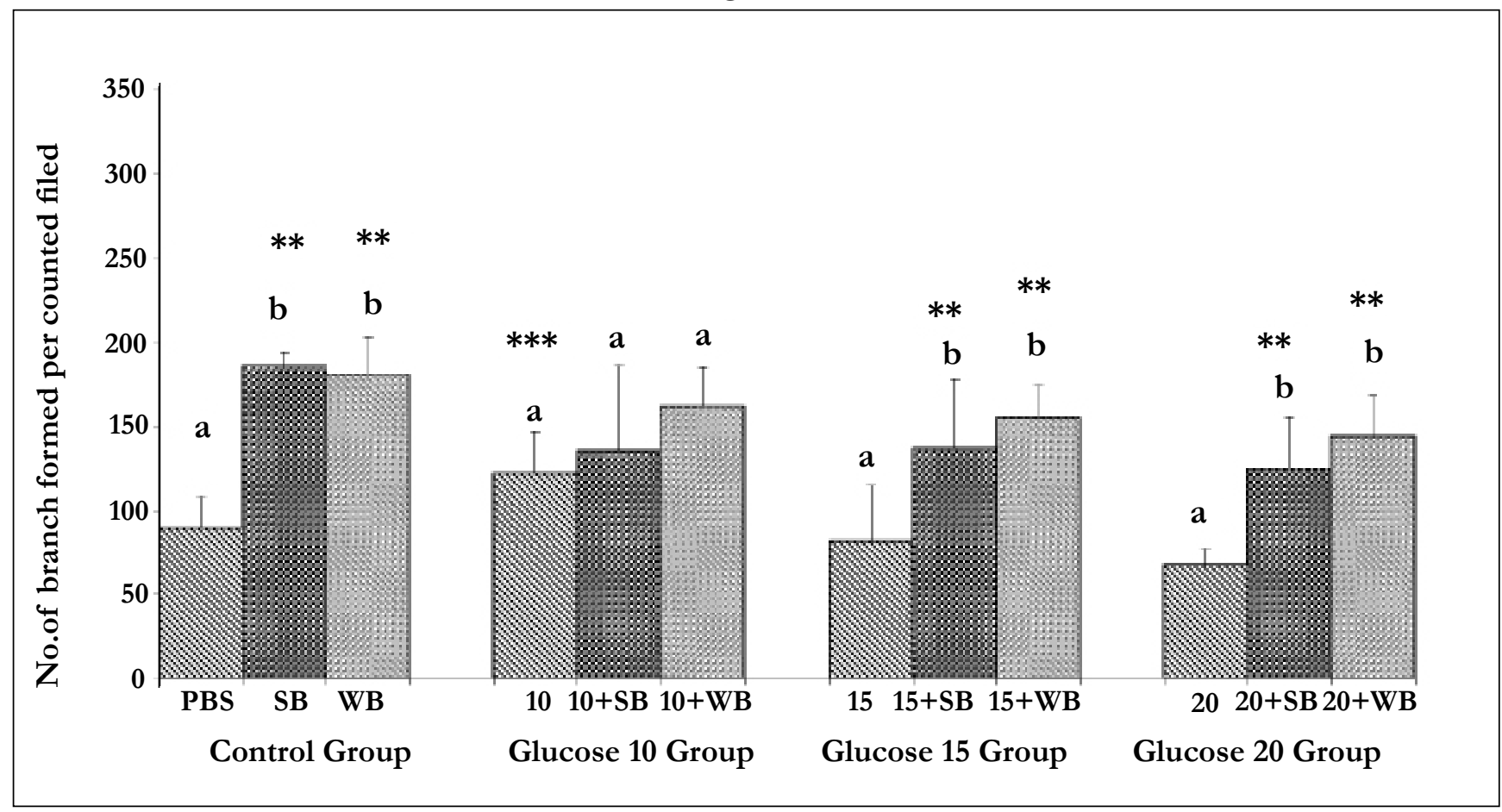

Histograms represent mean \pm SD capillary-like tube formation in the presence of different concentrations of glucose (Glucose 10 group-10 mM, Glucose 10 group-15 mM and Glucose 10 group $20 \mathrm{mM}$ - different treatment groups) in the presence of strawberry (SB) or wild blue berry (WB) extracts in vitro in HUVECs. Different letters represent significant difference $(\mathrm{p}<0.05)$ within each treatment group. ${ }^{*}, \mathrm{p}<0.05,{ }^{* *}, \mathrm{p}<0.01,{ }^{* * *}, \mathrm{p}<0.001$, vs. PBS treated control, $\mathrm{n}=3$.

Figure 7: Histograms represent mean \pm SD capillary-like tube formation in the presence of different concentrations of free fatty acids

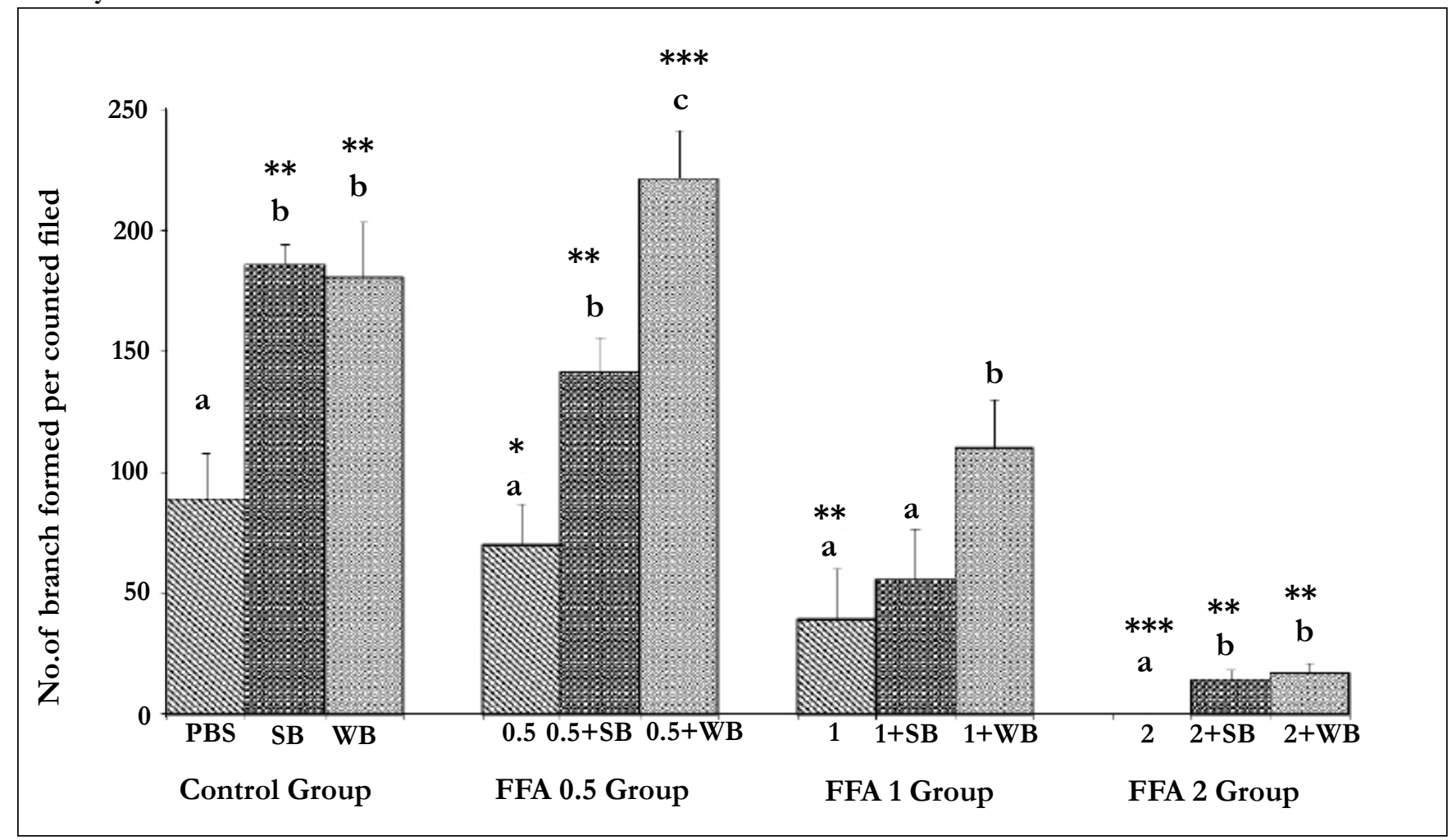

Histograms represent mean \pm SD capillary-like tube formation in the presence of different concentrations of free fatty acids acids (FFA 0.5 group- $0.5 \mathrm{mM}$, FFA 1 group- $1 \mathrm{mM}$, FFA 2 group- $2 \mathrm{mM}$ - different treatment groups) in the presence of strawberry (SB) or wild blue berry (WB) extracts in vitro in HUVECs. Different letters represent significant difference $(\mathrm{p}<0.05)$ within each treatment group. ${ }^{*}, \mathrm{p}<0.05, * *, p<0.01, * * *, p<0.001$, vs. PBS treated control, $\mathrm{n}=3$. 
Figure 8: Histograms represent mean \pm SD capillary-like tube formation in the presence of different concentrations

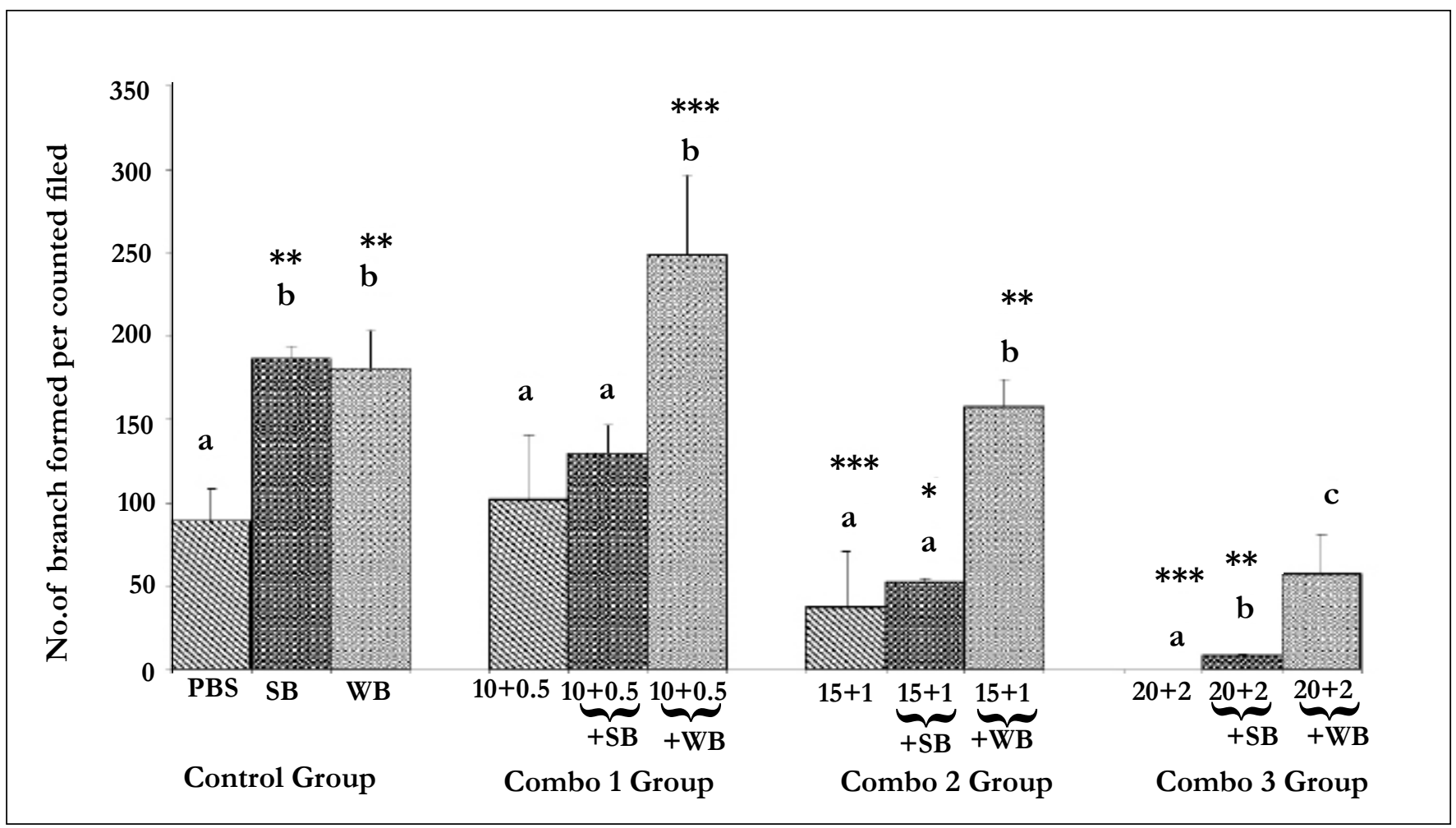

Histograms represent mean \pm SD capillary-like tube formation in the presence of different concentrations of (Combo 1 group-glucose $10 \mathrm{mM}+\mathrm{FFA} 0.5 \mathrm{mM}$, Combo 2 group- glucose $15 \mathrm{mM}+$ FFA $1 \mathrm{mM}$, Combo 3group-glucose $20 \mathrm{mM}+\mathrm{FFA} 2 \mathrm{mM}$ )) in the presence of strawberry (SB) or wild blue berry (WB) extracts in-vitro in HUVECs. Different letters represent significant difference $(\mathrm{p}<0.05)$ within each treatment group. ${ }^{*}, \mathrm{p}<0.05,{ }^{* *}, \mathrm{p}<0.01,{ }^{* * *}, \mathrm{p}<0.001$, vs. PBS treated control, $\mathrm{n}=3$.

Effects of fruit extracts with glucose and/or FFA on angiogenesis (capillary-like tube formation) in vitro in HUVECs

Glucose: Angiogenesis was assessed by observing capillary-like tube formation in vitro in HUVECs. Capillary-like tube formation was significantly increased in response to SB and WB extracts compared to the PBS control $(\mathrm{p}<0.05)$ (Figure 5-8). Furthermore, capillary-like tube formation was significantly enhanced in response to $10 \mathrm{mM}$ glucose treatment $(\mathrm{p}<0.05)$, but did not increase significantly at higher concentrations $(15 \mathrm{mM}$ and $20 \mathrm{mM})$ compared to the PBS control ( $\mathrm{p}>0.05$ ) (Figure 6). Although capillarylike tube formation was not significantly enhanced in response to the pre-treatment of cells with SB or WB ( $>>0.05)$, when HUVECs were incubated with $10 \mathrm{mM}$ glucose, SB or WB significantly enhanced capillary-like tube formation in cells treated with high concentrations of glucose $(15 \mathrm{mM}$ and $20 \mathrm{mM})$ compared to control experiments without SB or WB extracts $(\mathrm{p}<0.05)$.
FFA: Capillary-like tube formation exhibited a dose-dependent decrease in response to FFA treatment compared to the control $(\mathrm{p}<0.05, \mathrm{p}<0.01$ and $\mathrm{p}<0.001$ for $0.5 \mathrm{mM}, 1 \mathrm{mM}$ and $2 \mathrm{mM}$ FFA, respectively; Figure 7). FFA-induced impaired capillary-like tube formation was attenuated with $\mathrm{SB}$ and WB pre-treatment compared to their respective nutrient controls without fruit pretreatment. However, at $2 \mathrm{mM}$ FFA concentrations, we observed significantly less capillary-like tube formation in cells pre-treated with SB or WB than the PBS control $(\mathrm{p}<0.05)$.

Nutrient Combinations: Tube formation was significantly decreased in cells treated with $15 \mathrm{mM}$ glucose $+1 \mathrm{mM} \mathrm{FFA}$, and 20 $\mathrm{mM}$ glucose $+2 \mathrm{mM}$ FFA compared to the PBS control $(\mathrm{p}<0.05$; Figure 8). At the highest concentrations tested $(20 \mathrm{mM}$ glucose $+2 \mathrm{mM}$ FFA), tube formation was completely abolished. Pretreatment of cells with WB significantly attenuated the impaired tube formation induced by $15 \mathrm{mM}$ glucose $+1 \mathrm{mM}$ FFA and 20 $\mathrm{mM}$ glucose $+2 \mathrm{mM}$ FFA $(\mathrm{p}<0.05)$. In contrast, pre-treatment

Table 1: Anthocyanin composition of strawberry (SB) powder (mg/10 g)

\begin{tabular}{|l|l|}
\hline Compound & $\mathbf{m g} / \mathbf{1 0} \mathbf{~ g}$ \\
\hline 1.Pelargonidin-3-diglucoside & $0.37 \pm 0.41$ \\
\hline 2. Cyanidin-3-O-glucoside & $0.80 \pm 0.02$ \\
\hline 3. Pelargonidin-3-O-glucoside & $67.99 \pm 5.1$ \\
\hline 4. Pelargonidin-3-O-rutinoside & $2.35 \pm 0.13$ \\
\hline $\begin{array}{l}\text { 5. 5-Pyranopelargonidin-3-gluco- } \\
\text { side }\end{array}$ & $0.42 \pm 0.03$ \\
\hline \begin{tabular}{l} 
6. Pelagonidin-3-malonylglucoside \\
\hline $\begin{array}{l}\text { 7. Pelagonidin-3-malonylrhamno- } \\
\text { side }\end{array}$
\end{tabular} & $9.48 \pm 0.58$ \\
\hline Total detected anthocyanins & $8.24 \pm 0.00$ \\
\hline
\end{tabular}


Table 2: Anthocyanin composition of wild blueberry (WB) powder (mg/10 g)

\begin{tabular}{|l|l|}
\hline Compound & $\mathbf{m g} / \mathbf{1 0} \mathbf{g}$ \\
\hline 1. Delphinidin 3- O-galactoside & $6.5 \pm 2.8$ \\
\hline 2. Delphinidin 3- O-glucoside & $4.0 \pm 2.7$ \\
\hline 3. Cyanidin 3- O-galactoside & $9.5 \pm 4.6$ \\
\hline 4. Cyanidin 3- O-glucoside & $5.8 \pm 2.3$ \\
\hline 5. Petunidin 3- O- galactoside & $1.1 \pm 0.8$ \\
\hline 6. Cyanidin 3- O-arabinoside & $2.7 \pm 0.7$ \\
\hline 7. Petunidin 3- O- glucoside & $4.9 \pm 2.2$ \\
\hline 8. Peonidin-3-O-galactoside & $7.6 \pm 3.3$ \\
\hline 9. Peonidin-3-O-glucoside & $2.3 \pm 5.6$ \\
\hline 10. Malvidin-3- O- galactoside & $8.9 \pm 2.4$ \\
\hline 11. Malvidin-3- O- glucoside & $13.1 \pm 2.8$ \\
\hline 12. Malvidin-3- O-arabinoside & $5.2 \pm 2.4$ \\
\hline $\begin{array}{l}\text { 13. Delphinidin-3-(6"-acetoyl) } \\
\text { glucoside }\end{array}$ & $1.4 \pm 0.5$ \\
\hline 14. Cyanidin-3-(6"-acetoyl)glucoside & $1.1 \pm 0.5$ \\
\hline 15. Petunidin-3-(6"-acetoyl)glucoside & $0.8 \pm 0.2$ \\
\hline 16. Malvidin-3-(6"-acetoyl)glucoside & $7.6 \pm 3.5$ \\
\hline Total detected anthocyanins & 82.5 \\
\hline
\end{tabular}

FFA: Capillary-like tube formation exhibited a dose-dependent decrease in response to FFA treatment compared to the control $(\mathrm{p}<0.05, \mathrm{p}<0.01$ and $\mathrm{p}<0.001$ for $0.5 \mathrm{mM}, 1 \mathrm{mM}$ and $2 \mathrm{mM}$ FFA, respectively; Figure 7). FFA-induced impaired capillary-like tube formation was attenuated with SB and WB pre-treatment compared to their respective nutrient controls without fruit pretreatment. However, at $2 \mathrm{mM}$ FFA concentrations, we observed significantly less capillary-like tube formation in cells pre-treated with SB or WB than the PBS control $(\mathrm{p}<0.05)$.

Nutrient Combinations: Tube formation was significantly decreased in cells treated with $15 \mathrm{mM}$ glucose $+1 \mathrm{mM} \mathrm{FFA}$, and 20 $\mathrm{mM}$ glucose $+2 \mathrm{mM}$ FFA compared to the PBS control $(\mathrm{p}<0.05$; Figure 8$)$. At the highest concentrations tested $(20 \mathrm{mM}$ glucose $+2 \mathrm{mM}$ FFA), tube formation was completely abolished. Pretreatment of cells with WB significantly attenuated the impaired tube formation induced by $15 \mathrm{mM}$ glucose $+1 \mathrm{mM}$ FFA and 20 $\mathrm{mM}$ glucose $+2 \mathrm{mM}$ FFA $(\mathrm{p}<0.05)$. In contrast, pre-treatment of cells with $\mathrm{SB}$ was not effective in restoring tube formation impaired by all combinations tested. Microscopic images showed that the quality of tube formation (length and completeness of branches) was reduced at the two higher glucose concentrations (15 and $20 \mathrm{mM}$ ), all three FFA concentrations $(0.5-2 \mathrm{mM})$ and in all combinations compared to the PBS control (Figure 5).

\section{Anthocyanin content of SB and WB}

The composition of the SB and WB powders used in this study was published previously.[9, 17] Table 1 and 2 shows identity and amounts of the major anthocyanins in SB and WB powders. The most abundant anthocyanin in SB powder was pelargonidin-3-Oglucoside $(67.99 \pm 5.1 \mathrm{mg} / 10 \mathrm{~g})$, followed by pelargonidin-3-Omalonylglucoside $(9.48 \pm 0.58 \mathrm{mg} / 10 \mathrm{~g})$. In WB samples, malvidin-3- O -glucoside $(13.1 \pm 2.8 \mathrm{mg} / 10 \mathrm{~g})$ was the most abundant compound, followed by cyanidin 3 - $\mathrm{O}$-galactoside $(9.5 \pm 4.6$ $\mathrm{mg} / 10 \mathrm{~g})$ and malvidin-3- $\mathrm{O}-$ galactoside $(8.9 \pm 2.4 \mathrm{mg} / 10 \mathrm{~g})$. The total anthocyanin contents of berry extracts $(0.2 \mathrm{mg} / \mathrm{mL})$ used in the cell migration and capillary-like tube formation assays were 2.04 and $2.06 \mu \mathrm{g} / \mathrm{mL}$ for SB and WB, respectively.

The total phenolic content for SB and WB powders was $125.51 \pm$ 2.34 and $122.68 \pm 7.87 \mu \mathrm{g}$ gallic acid equivalents (GAE) $/ 10 \mathrm{~g}$, respectively as determined in a colorimetric assay. These values corresponded to $6.28 \pm 0.12$ and $6.13 \pm 0.39 \mu \mathrm{g}$ GAE $/ \mathrm{mL}$ of $\mathrm{SB}$ and WB extracts used in the cell migration and tube formation assays.

The ascorbic acid contents of the SB and WB powders were 22.8 \pm 0.48 and $0.08 \pm 0.00 \mathrm{mg}$ ascorbic acid $/ 10 \mathrm{~g}$, respectively. These values corresponded to $0.57 \pm 0.01$ and $0.02 \pm 0.00 \mu \mathrm{g}$ ascorbic acid $/ \mathrm{mL} \mathrm{SB}$ and WB extracts used in the in vitro studies

\section{Discussion}

In the present study, we investigated the effect of anthocyaninrich extracts of strawberry (SB) and wild blueberry (WB) on impaired endothelial function as assessed by cell migration and capillary-like tube formation induced by relatively high glucose, FFA, and combinations of glucose + FFA in vitro in endothelial cells. Treatment concentrations were high with respect to physiologically concentrations for a healthy fasting human, yet are typically seen in the fasting and postprandial states for pre-diabetic and diabetic individuals. Several studies have suggested that fruits rich in polyphenolic antioxidants modulate endothelial cell function including cell migration and angiogenesis. $[9,11,15,18]$ In our previous study, anthocyanin-rich extracts of SB and WB significantly enhanced cell migration and capillary-like tube formation compared to a PBS control in vitro in HUVECs. [9]

Bioavailability is a key factor in determining the effects of foodderived polyphenols on physiological effects in humans. In recent years, cell culture studies have come under scrutiny when studying extracts of fruit due to difference in metabolite profiles in vivo vs components used in vitro. While this is an important consideration and the subject of future research, the study of extracts is not 
entirely irrelevant at least in the case of anthocyanins. Several in vivo studies have demonstrated that anthocyanin compounds such as anthocyanin glycosides and aglycones can indeed be absorbed intact, although plasma levels are in the low nM range. [15] [19].

Data from the present in vitro study indicated that cell migration and capillary-like tube formation were significantly decreased in the presence of high FFA and combinations of glucose + FFA compared to the PBS control in vitro in HUVECs. However, pretreatment of cells with either SB or WB extracts attenuated the impaired endothelial cell migration and capillary-like tube formation induced by high FFA, and combinations of glucose and FFA.

Plant foods, particularly fruits have been identified as dietary components that could reduce the risk in humans of developing chronic diseases. [7] Dietary antioxidants, especially polyphenolic compounds present in fruits are thought to be responsible at least in part for the beneficial effects.[20],[21] The chemical basis for the desirable properties of polyphenolic compounds is believed to be their ability to change the endogenous redox status of the cell thereby modulating cell-signaling pathways. [9] [22], [23] In the present study, anthocyanins and total polyphenolic compounds in the cell culture media containing SB or WB were not significantly different as measured by chromatographic techniques and a colorimetric assay (Folin assay). However, in addition to polyphenolic compounds, SB and WB contain ascorbic acid, another potential antioxidant that can contribute to the redox status of the cells. In our previous study, we demonstrated that in addition to polyphenolic compounds, ascorbic acid can activate the redox-sensitive Akt/e-NOS signaling pathway in vitro in HUVEC. [24] Furthermore, Dudgeone et al demonstrated that ascorbic acid concentrations in the range of $1-300 \mu \mathrm{mol} / \mathrm{L}$ activated endothelial dependent relaxation signals. [25] In our study, the ascorbic acid content of the SB extract was $0.57 \pm 0.01 \mu \mathrm{g} /$ $\mathrm{mL}(\sim 3.2 \mu \mathrm{mol} / \mathrm{L})$ while the concentration in the WB extract was $\sim 20$ fold less. However, in the present study, cell migration and capillary -like tube formation in response to SB and WB were not found to be significantly different. Therefore, it can be suggested that cell migration and capillary -like tube formation in response to $\mathrm{SB}$ and $\mathrm{WB}$ were predominately governed by polyphenolic compounds in the extracts.

Our previous work showed that SB and WB induced HUVECs migration and capillary-like tube formation via the redox sensitive PI3/Akt kinase pathway in vitro. [9] Endothelial cell migration and capillary-like tube formation are mediated by an endothelial nitric oxide synthase (eNOS) dependent mechanism requiring activation downstream signaling of $\mathrm{PI} 3 \mathrm{~K} / \mathrm{Akt}$, which phosphorylates eNOS.[26] Impaired activation/expression of eNOS and/ or reduced bioavailability of its product, nitric oxide, results in impaired endothelial function.[27] Relatively high glucose and FFA are known to impair the activation of eNOS, alter eNOS expression and enhance nitrated tyrosine content in endothelial cells [28-30] Therefore, we propose that the decreased cell migration and capillary-like tube formation induced by the high FFA and combination of high glucose and FFA treatments is due to impaired activation/expression of eNOS and/or decreased bioavailability of nitric oxide. In the present investigation, SB and WB extracts attenuated cell migration and capillary-like tube formation in cells treated with FFA and combinations of FFA + glucose. Therefore, it is reasonable to hypothesize that observed effects in the present study, were at least in part due to the activation of $\mathrm{PI} 3 \mathrm{~K} / \mathrm{Akt} / \mathrm{eNOS}$ activation in the presence of SB or WB.
Polyphenolic antioxidants are known to activate the signaling molecules that enhance endogenous antioxidant defense mechanisms. $[22,31]$ Experimental data strongly suggest that dietary polyphenols can stimulate antioxidant enzyme transcription through antioxidant responsive elements.[31] In the present study, HUVECs were pretreated with SB or WB $2 \mathrm{~h}$ before the treatment of glucose and/or FFA. Therefore, HUVEC cells may have augmented endogenous antioxidants and/or enzymes related to antioxidant defense by the time they were exposed to glucose and/or FFA. Therefore, preservation of endothelial cell migration and capillary-like tube formation in the presence of fruit extracts with and without nutrient loads may also be due to stimulation of endogenous defense systems resulting in cellular redox shifts. However, further mechanistic in vitro and in vivo studies are needed to confirm this mechanism.

Several studies suggested that that elevated glucose and FFA levels lead to endothelial dysfunction. [29,30] The endothelial cell is paramount to cardiovascular health and is functionally sensitive to oxidative stress. [27] The relative increases in glucose and/or FFA levels generally observed in individuals with IR are known to increase reactive oxygen species (ROS) production resulting in activation of stress sensitive signaling pathways. [1] Moreover, human clinical data derived from our laboratory indicated that high levels of plasma glucose and blood lipids result in augmentation of oxidative stress especially in the postprandial state. [15] The postprandial state is characterized by relatively high glucose and FFA with metabolic trafficking, biosynthesis, oxidative metabolism and formation of ROS. [32] Postprandial hyperglycemia and hyperlipidemia induced by typical Western-type meals rich in lipids and carbohydrates induce oxidative stress and endothelial dysfunction. [33] These effects are exaggerated in overweight/ obese individuals and are characteristic features of IR. [15] Therefore, it can be suggested that inclusion of SB or WB in the daily diet will have significant benefits on cardio-metabolic functions.

Angiogenesis and cell migration are important factors in the progression of cancers. Therefore, one can argue that polyphenolic compounds will stimulate the progression of cancers especially people with relative high glucose and FFA, based on the data from the present study. It has been demonstrated that higher levels of polyphenolic compounds (in $>10 \mu \mathrm{M}$ range) inhibit angiogenesis and cell migration in vitro studies. [34, 35] However, a relatively low concentration of polyphenolic compounds $(<10$ $\mu \mathrm{M})$ as observed in the present study enhance angiogenesis and endothelial cell migration. $[9,35]$ More work is needed to examine the effects of polyphenol- rich fruit extracts in combination with glucose and/or FFA treatments on angiogenesis and cell migration in cancer cells.

In summary, the data from the present in vitro study indicated the beneficial effects of SB and WB extracts on endothelial function for cells presented to relatively high concentrations of FFA and combination of glucose + FFA. Furthermore, the data from the present study may help to understand the mechanism behind the impaired endothelial function in individuals with IR or uncontrolled diabetic conditions, and those in the postprandial state, especially after a consumption of a Western-type high carbohydrate and high fat diet.

\section{Author Contributions}

Indika Edirisinghe, Britt Burton-Freeman, and Lauren Jackson designed the research. Claire Chang, Indika Edirisinghe and Arch- 
ana Kangath, conducted the research. Claire Chang and Indika Edirisinghe analyzed the data and compiled the manuscript. All authors read and approved the final submitted manuscript. Authors declared no conflicts of interest with the project.

\section{Disclaimer}

Claire Chang and Lauren S. Jackson's scientific views and opinions expressed in this paper are those of the individual author's and do not necessary reflect those scientific views of the U.S. Food and Drug Administration.

\section{Funding Sources}

Funding for this project was provided by FDA/NCFST co-operative agreement grant.

\section{Acknowledgment}

We are grateful to the Wild Blueberry Association of North America for providing wild blueberry and California Strawberry Commission for providing freeze dried strawberry powder. Artemio Tulio and Katie Banaseweki helped in analyzing fruit extracts.

\section{References}

[1] Boden G (2003) Effects of free fatty acids (FFA) on glucose metabolism: significance for insulin 410 resistance and type 2 diabetes. Exp Clin Endocrinol Diabetes 111: 121-4.

[2] Bryan S, Baregzay B, Spicer D, Singal P K, Khaper N (2013) Redox-inflammatory synergy in the metabolic syndrome. Can J Physiol Pharmacol 91: 22-30.

[3] Montero D, Walther G, Perez-Martin A, Roche E, Vinet A (2012) Endothelial dysfunction, inflammation, and oxidative stress in obese children and adolescents: markers and effect of lifestyle intervention. Obes Rev 13: 441-55.

[4] Zhang H, Dellsperger K C, Zhang C (2012) The link between metabolic abnormalities and endothelial dysfunction in type 2 diabetes: an update. Basic Res Cardiol 107: 237.

[5] Kolluru G K, Bir S C, Kevil C G (2012) Endothelial dysfunction and diabetes: effects on angiogenesis, vascular remodeling, and wound healing. Int J Vasc Med In press. doi: 10.1155/2012/918267.

[6] Gilbert R E (2013) Endothelial loss and repair in the vascular complications of diabetes: pathogenetic mechanisms and therapeutic implications. Circ J 77: 849-56.

[7] Soory M (2012) Nutritional antioxidants and their applications in cardiometabolic diseases. Infect Disord Drug Targets 12: 388-401.

[8] Edirisinghe I, Burton-Freeman B, Tissa Kappagoda C (2008) Mechanism of the endothelium-dependent relaxation evoked by a grape seed extract. Clin Sci (Lond) 114: 331-7.

[9] Tulio A Z, Chang C, Edirisinghe I, White K D, Jablonski J E et al. (2012) Berry Fruits Modulated Endothelial Cell Migration and Angiogenesis via Phosphoinositide-3 Kinase/Protein Kinase B Pathway in Vitro in Endothelial Cells. J Agric Food Chem. 60:5803-5812

[10] Sivaprakasapillai B, Edirisinghe I, Randolph J, Steinberg F,. Kappagoda T (2009) Effect of grape seed extract on blood pressure in subjects with the metabolic syndrome. Metabolism 58: 1743-1746.

[11] Schini-Kerth V B, Etienne-Selloum N, Chataigneau T, Auger C (2011) Vascular protection by natural product-derived polyphenols: in vitro and in vivo evidence. Planta Med 77: 1161-1167.

[12] Inoguchi T,Li P, Umeda F, Yu H Y, Kakimoto M,et al. (2000) High glucose level and free fatty acid stimulate reactive oxygen species production through protein kinase C--dependent activation of NAD(P)H oxidase in cultured vascular cells. Diabetes 49: 1939-45.

[13] Creager M. A, Lüscher T F, Cosentino F, Beckman J A (2003) Diabetes and vascular disease: pathophysiology, clinic,al consequences, and medical therapy: Part I. Circulation 108: 1527-32.

[14] Salameh A, Zinn M, Dhein S (1997) High D-glucose induces alterations of endothelial cell structure in a cell-culture model. J Cardiovasc Pharmacol 30: 182-90.

[15] Edirisinghe I, Banaszewski K, Cappozzo J, Sandhya K, Ellis C L et al. (2011) Strawberry anthocyanin and its association with postprandial inflammation and insulin. Br J Nutr 106: 913-22.
[16] Slinkard K, Singleton V L (1977) Total phenol analysis: automation and comparison with manual 444 methods. Amer. J. Enol. Vitic. 28: 49-55.

[17] Sanchez-Mata M C, Camara-Hurtado M, Diez-Marques C, Torija-Isasa M E (2000) Comparison of high- performance liquid chromatography and spectrofluorimetry for vitamin C analysis of green beans (Phaseolus Vulgaris L.). Eur. Food Res. Technol 210: 220-225.

[18] Stoclet J C, Chataigneau T, Ndiaye M, Oak M H;, El Bedoui J et al. (2004) Vascular protection by dietary polyphenols. Eur J Pharmacol 500: 299-313.

[19] McGhie T K, Ainge G D Barnett L E Cooney J M, Jensen D J(2003) Anthocyanin glycosides from berry fruit are absorbed and excreted unmetabolized by both humans and rats. J Agric Food Chem 51: 4539-4548.

[20] Khurana S Venkataraman K, Hollingsworth A, Piche M Tai T C (2013) Polyphenols: benefits to the cardiovascular system in health and in aging. Nutrients 5:3779-3827.

[21] Vauzour D, Rodriguez-Mateos A, Corona G, Oruna-Concha M J, Spencer J $\mathrm{P}(2010)$ Polyphenols and human health: prevention of disease and mechanisms of action. Nutrients 2: 1106-1131.

[22] Scalbert A, Johnson I T, Saltmarsh M,(2005) Polyphenols: antioxidants and beyond. Am J Clin Nutr 81, 215S-217S.

[23] Edirisinghe I, Burton-Freeman B, Varelis P, Kappagoda T,(2008) Strawberry extract caused endothelium-dependent relaxation through the activation of PI3 kinase/Akt. J Agric Food Chem 56: 9383-9390.

[24] Edirisinghe I, Banaszewski K, Cappozzo J, McCarthy D, and Burton-Freeman BM (2011) Effect of Black Currant Anthocyanins on the Activation of Endothelial Nitric Oxide Synthase (eNOS) in Vitro in Human Endothelial Cells. J. Agric. Food Chem.59: 8616-8624

[25] Dudgeon S, Benson D P, MacKenzie A, Paisley-Zyszkiewicz K, Martin W (1998). Recovery by ascorbate of impaired nitric oxide dependent relaxation resulting from oxidant stress in rat aorta. Br. J. Pharmacol. 125: 782-726.

[26] Edirisinghe I, Yang S R, Yao H, Rajendrasozhan S, Caito S,et al. (2008) VEGFR-2 inhibition augments cigarette smoke-induced oxidative stress and inflammatory responses leading to endothelial dysfunction. FASEB J 22:2297-310.

[27] Lee R, Channon K M Antoniades C(2012) Therapeutic strategies targeting endothelial function in humans: clinical implications. Curr Vasc Pharmacol 10:77-93

[28] El-Remessy A B, Abou-Mohamed G, Caldwell R W, Caldwell R B(2003) High glucose-induced tyrosine nitration in endothelial cells: role of eNOS uncoupling and aldose reductase activation. Invest Ophthalmol Vis Sci 44:3135-3143.

[29] HinkU,Li H Mollnau H Oelze M Matheis Eet al. (2001) Mechanisms underlying endothelial dysfunction in diabetes mellitus. Circ Res 88: E14-22.

[30] Rogers S C, Zhang X, Azhar G, Luo S, Wei J Y (2013) Exposure to High or Low Glucose Levels Accelerates the Appearance of Markers of Endothelial Cell Senescence and Induces Dysregulation of Nitric Oxide Synthase. J Gerontol A Biol Sci Med Sci 68:1469-1481.

[31] Masella R, Di Benedetto R, Varì R, Filesi C, Giovannini C(2005) Novel mechanisms of natural antioxidant compounds in biological systems: involvement of glutathione and glutathione-related enzymes. J Nutr Biochem 16:577-86.

[32] Alvarez J A, Higgins P B, Oster R A, Fernandez J R, Darnell B Eet al. (2009) Fasting and postprandial markers of inflammation in lean and overweight children. Am J Clin Nutr 89: 1138-1144.

[33] Alipour A, Elte J,W, van Zaanen H C, Rietveld A P, Cabezas M C(2007) Postprandial inflammation and endothelial dysfuction. Biochem Soc Trans 35: 466-469.

[34] Asensi M,Ortega A, Mena S, Feddi F, Estrela J M (2011) Natural polyphenols in cancer therapy. Crit Rev Clin Lab Sci 48:197-216.

[35] Chen C M, Li S C, Chen C Y, Au H K, Shih C K et al. (2011); Constituents in purple sweet potato leaves inhibit in vitro angiogenesis with opposite effects ex vivo. Nutrition 27: 1177-1182. 